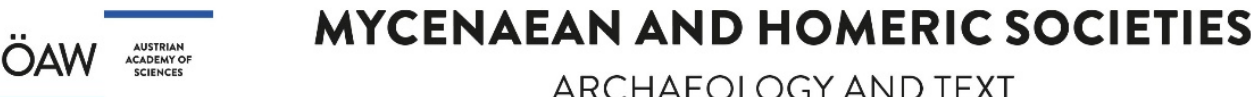 \\ ARCHAEOLOGY AND TEXT
}

Collected Papers of

\section{SIGRID DEGER-JALKOTZY}

edited by Birgitta Eder and Ulrike Schuh

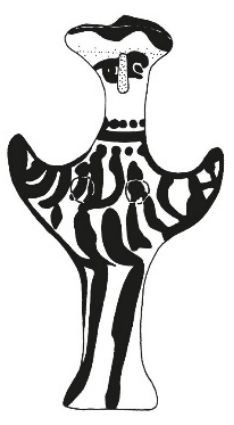

82.

S. Deger-Jalkotzy

Cremation Burials in the Mycenaean Cemetery of Elateia-Alonaki in Central Greece

in: M. Lochner - F. Ruppenstein (eds.), Brandbestattungen von der mittleren Donau bis zur Ägäis zwischen 1300 und 750 v. Chr. Akten des internationalen Symposiums an der Österreichischen Akademie der Wissenschaften in Wien, 11.-12. Februar 2010, Mitteilungen der Prähistorischen Kommission $77=$ Veröffentlichungen der Mykenischen Kommission $32=$ Österreichische Akademie der Wissenschaften philosophisch-historische Klasse Denkschriften 448 (Vienna 2013) 221-229

(c) Verlag der ÖAW

mit freundlicher Genehmigung / with kind permission

Dieses Dokument darf ausschließlich für wissenschaftliche Zwecke genutzt werden (Lizenz CC BY-NC-ND), gewerbliche Nutzung wird urheberrechtlich verfolgt. 
Michaela Lochner, Florian Ruppenstein (Hrsg.)

Brandbestattungen von der mittleren Donau

bis zur Ägäis zwischen 1300 und 750 v. Chr.

Cremation burials in the region between the Middle Danube and the Aegean, 1300-750 BC 
Österreichische Akademie der Wissenschaften

Denkschriften der philosophisch-historischen Klasse,

448. Band

\section{Mitteilungen der Prähistorischen}

Kommission

Herausgegeben von Herwig Friesinger

\section{Band 77}

Redaktion: Michaela Lochner

Veröffentlichungen der Mykenischen Kommission

Herausgegeben von Hermann Hunger

\section{Band 32}


Michaela Lochner, Florian Ruppenstein (Hrsg.)

\section{Brandbestattungen von der mittleren Donau bis zur Ägäis zwischen 1300 und 750 v. Chr \\ Akten des internationalen Symposiums an der Österreichischen Akademie der Wissenschaften in Wien, 11.-12. Februar 2010}

Cremation burials in the region between the Middle Danube and the Aegean, 1300-750 BC

Proceedings of the international symposium held at the Austrian Academy of Sciences at Vienna,

February $11^{\text {th }}-12^{\text {th }}, 2010$

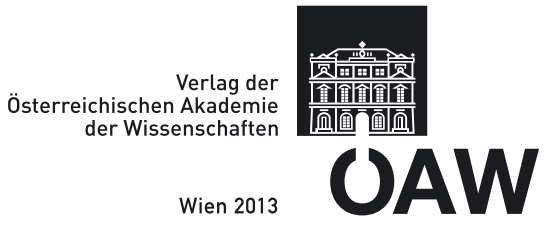


Vorgelegt von

w. M. Sigrid Deger-Jalkotzy

w. M. Herwig Friesinger in der

Sitzung am 16. März 2012

Veröffentlicht mit

Unterstützung des

Austrian Science Fund

(FWF): PUB 34-G19

\section{Der Wissenschaftsfonds.}

Umschlagbild: Grafik Gregor Hartmann

Lektorat:

Sigrid Strohschneider-Laue (dt.)

Nicola Nightingale (en.)

Layoutkonzept: Thomas Melichar

Umschlaggestaltung: Marion Frauenglas

Die verwendeten Papiersorten sind

aus chlorfrei gebleichten Zellstoff

hergestellt, frei von säurebildenden

Bestandteilen und alterungsbeständig.

Alle Rechte vorbehalten

ISBN 978-3-7001-7260-4

ISSN 0065-5376

Copyright $(\subset) 2013$ by Österreichische

Akademie der Wissenschaften, Wien

Satz und Umsetzung des Layouts:

Druckerei Ferdinand Berger \&

Söhne Ges.m.b.H., 3580 Horn

Druck und Bindung:

digiDruck GesmbH, Wien

http: //hw. oeaw.ac.at/7260-4

http: //verlag.oeaw.ac.at 


\section{Inhaltsverzeichnis/Table of content}

Vorwort/Preface - 7

\section{Michaela Lochner}

Bestattungssitten auf Gräberfeldern der

mitteldonauländischen Urnenfelderkultur - 11

\section{Andreas Lippert}

Brandbestattungen der Urnenfelderzeit in der

Steiermark - 33

\section{Gabor Vaczi}

Cultural connections and interactions in the Late Bronze Age cemetery of Budapest-Békásmegyer, Hungary - 45

\section{Carol Kacsó}

Spätbronzezeitliche Brandbestattungen im

Norden Siebenbürgens - 63

Matija Črešnar, Jayne-Leigh Thomas

New data on cremation burials from North-Eastern Slovenia - 79

Daria Ložnjak Dizdar

Cremation burials in Northern Croatia

1300-750 BC - 99

\section{Snježana Karavanić}

The Velika Gorica cemetery and related sites in

Continental Croatia - 119

\section{Zdenko Žeravica †}

Brandbestattungssitten auf dem westlichen

Balkan zwischen 1300 und 750 v. Chr. - 135

\section{Mario Gavranović}

Spätbronze- und früheisenzeitliche Brandbestattungen südlich der Save. Naturräume und Tradition - 143

\section{Predrag Medović}

Brandbestattungen in Urnen im serbischen

Donaugebiet von 1300 bis 750 v. Chr. - 159

\section{Rastko Vasić}

Cremation burials in the Morava valley between 1300 and $750 \mathrm{BC}-173$

\section{Florian Ruppenstein}

Cremation burials in Greece from the Late Bronze Age to the Early Iron Age: continuity or change? - 185

Anna Lagia, Anastasia Papathanasiou, Zoi Malakasioti, Foteini Tsiouka Cremations of the Early Iron Age from Mound 36 at Voulokalyva (ancient Halos) in Thessaly: a bioarchaeological appraisal- 197

\section{Sigrid Deger-Jalkotzy}

Cremation burials in the Mycenaean cemetery of Elateia-Alonaki in Central Greece - 221 
Magdalini Valla, Sevasti Triantaphyllou,

Paul Halstead, Valasia Isaakidou

Handling of death at the end of the Late Bronze

Age: the case of Faia Petra, 13th c. BC, Eastern

Macedonia, Greece - 231

\section{Heleni Palaiologou}

Late Helladic IIIC cremation burials at Chania of Mycenae - 249

Abkürzungen/Abbreviations - 281 


\title{
Cremation burials in the Mycenaean cemetery of Elateia-Alonaki in Central Greece
}

\author{
Sigrid Deger-Jalkotzy
}

\section{Zusammenfassung}

BrandBestattungen in DER Mykenischen Nekropole von Elateia-Alonaki in Mittelgriechenland. In der Kammergrabnekropole von Elateia-Alonaki wurden etwa 2000 Erdbestattungen, aber nur 23 Brandbestattungen nachgewiesen, was einem Anteil von weniger als $2 \%$ entspricht. Die Nekropole war von der Phase SH IIIA 1 bis in frühprotogeometrische Zeit in Benutzung (ca. 1400 bis zum frühen 10. Jh. v. Chr.). Brandbestattung wurde nur am Übergang von der Spätbronzezeit zur Frühen Eisenzeit praktiziert. Die ältesten Brandbestattungen datieren in die Phase SH IIIC Spät, die jüngsten in die frühprotogeometrische Zeit. Nur drei Brandbestattungen waren in Urnen deponiert, die übrigen befanden sich auf dem Boden der Grabkammern. Verbrannt wurden Frauen, Männer, Jugendliche und Kinder, wobei deutlich mehr Frauen als Männer anthropologisch nachgewiesen werden konnten. Besondere Aufmerksamkeit verdienen drei Doppelbestattungen von Frauen mit Kleinkindern. Die Sitte der Brandbestattung wurde vielleicht von einer neuen Bevölkerungsgruppe in Elateia eingeführt.

\section{Abstract}

In the Mycenaean chamber tomb cemetery of ElateiaAlonaki ca. 2000 inhumations and only 23 cremation burials were found. This corresponds to a ratio of less than $2 \%$ for the cremations. The cemetery was in use from LH IIIA 1 to the Early Protogeometric period (ca. 1400 to the early $10^{\text {th }}$ century $\mathrm{BC}$ ). The practice of cremation was confined to the transitional period from the Late Bronze Age to the Early Iron Age. The earliest cremation burials date to LH IIIC Late, the latest to the Early Protogeometric period.
Only three cremations were contained in ash-urns. Otherwise cremation burials were deposited on the floors of the chamber tombs. The cremations were of women, men, juveniles and children. The anthropological analysis was able to show that much more women than men were cremated. Three double cremations each consisting of a woman and a small child are especially remarkable. The introduction of cremation as burial practice in Elateia is possibly connected to the arrival of a new population group.

The village of Elateia is situated in a plain along the upper valley of the Boeotian River Kephissos in the modern province of Phthiotis (Fig. 1). Approximately $6 \mathrm{kms}$ north of the village the foothills of the Kallidromos Mountains slope down to the plain. A Mycenaean cemetery was discovered in 1986 on a slope called Alonaki. Salvage excavations by the 14th Ephorate of Prehistoric and Classical Antiquities at Lamia under the direction of Phanouria Dakoronia conducted until 1987 brought 22 Mycenaean chamber-tombs to light. Subsequently a further 61 of these tombs and eight Roman graves were excavated between 1988 and 1991 under a joint project of the Ephorate at Lamia and the Institute of Ancient History at the University of Salzburg. The Austrian excavation team included the physical anthropologists Egon Reuer and Susanne Fabrizii-Reuer, to whom all anthropological data are owed. Moreover, S. Fabrizii-Reuer provided the details of the cremation technique referred to in this article. ${ }^{1}$

1. The present article is an English summary - augmented by some further evidence - of Dakoronia, Deger-Jalkotzy, FabriziReuer 2002. 


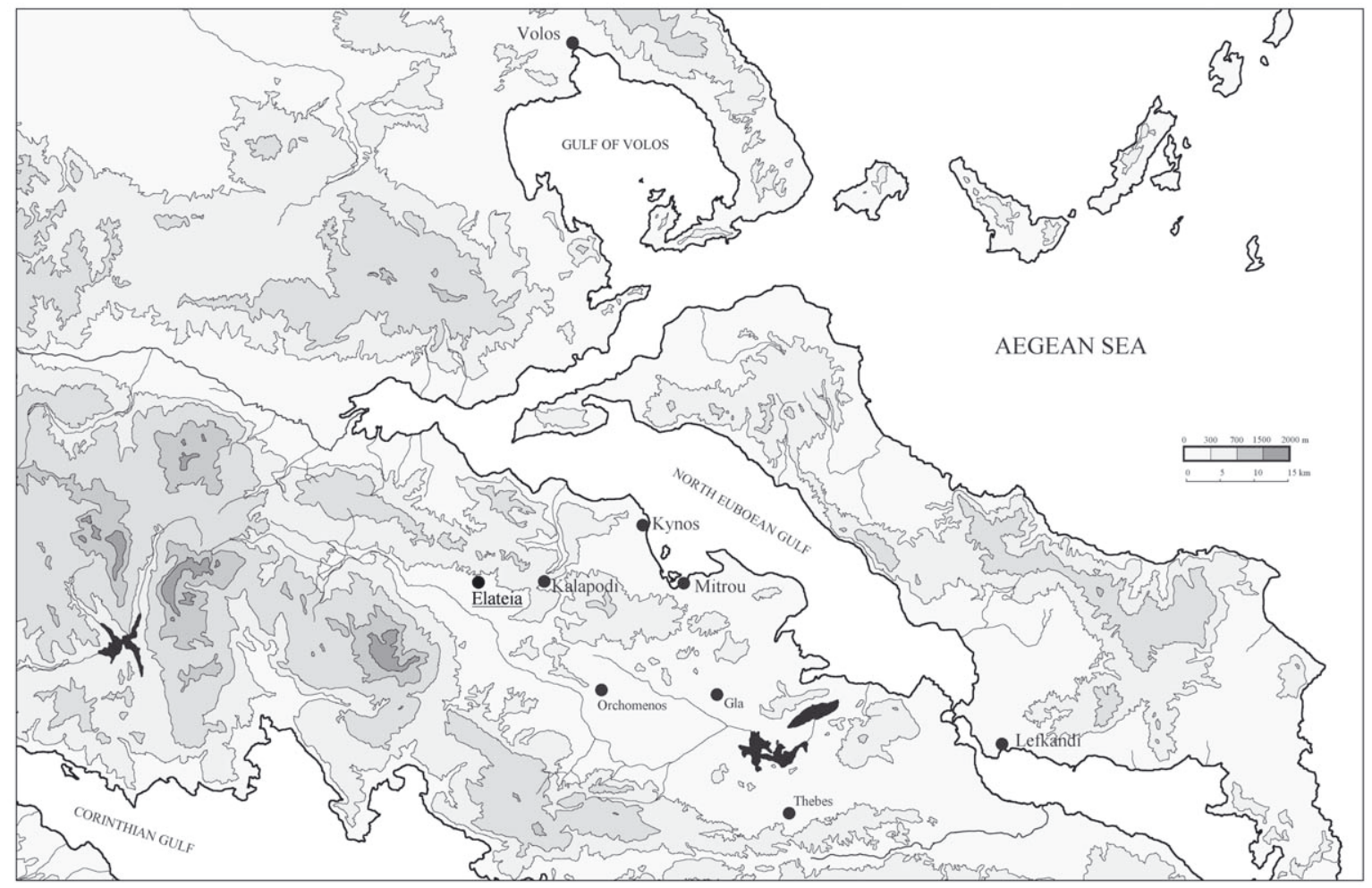

Fig. 1. The general area of Elateia and adjacent regions. (After Lis 2009, Fig. 1).

Of the 61 Mycenaean chamber-tombs excavated by the Greek-Austrian project 12 had been already destroyed in antiquity. The remaining 49 tombs contained the skeletal remains of 2.000 individuals, 23 of which were cremated.

2000 inhumations as opposed to 23 cremations, or a ratio of far less than $2 \%$, clearly suggest that cremation was not the usual form of burial in Elateia. This can also be concluded from the observation that the combustion temperature was mainly between 600 and 800 degrees centigrade, which is comparatively low. In order to cremate the corpse of an adult person at least three cubic metres of wood, dried for two years and then held in stock for another three years, was required. ${ }^{2}$ Apparently such material was not used in Elateia although sufficient wood would have been available from the Kallidromos Mountains. This suggests that this procedure was not practised in Elateia.

The chronology of the Elateia-Alonaki cemetery ranges from ca. $1400 \mathrm{BC}$ to the end of the late 11th and the early 10th centuries BC (Late Helladic IIIA 1 to Early Protogeometric). Some chamber-tombs were even used as late as the 9 th century. Most of the tombs were used throughout many

2. Dakoronia, Deger-Jalkotzy, Fabrizit-Reuer 2002, 147. - After Grupe, Herrmann 1983. generations. ${ }^{3}$ The dead bodies were deposited on the floors of the chambers. When no space was left for new interments, the remains of earlier burials, including the burial gifts, were pushed aside to the walls and corners of the chambers, or deposited in pits dug into the floors of the chambers and dromoi. $^{4}$

In contrast to the long-lasting use of the cemetery, the practice of cremation was confined to the transitional period from the Late Bronze Age to the Early Iron Age in Greece, i.e. to the $11^{\text {th }}$ and perhaps the early $10^{\text {th }}$ centuries BC (Fig. 2). It seems to have begun in LH IIIC Late, its height being reached during the Submycenaean period. A few cremations can be dated to Early Protogeometric. ${ }^{5}$ Cremations were only deposited in the chambers, both on the floor and in pits. No cremation was found in a dromos pit. Only three cremations were contained in ash-urns. They were of an Early Protogeometric date. Otherwise crema-

3. On the chronology of the Elateia-Alonaki cemetery see e.g. DEGER-JALKOTZY 2007, 143-145.

4. Deger-Jalkotzy, 2007.

5. The chronology of the cremation burials has been treated in depth in Dakoronia, Deger-Jalkotzy, Fabrizii-Reuer 2002. - See also Deger-JALKOTZy 2009, 84, $96 \mathrm{f}$. 
Elateia - Alonaki: Chronology of Cremation Burials (After Dakoronia - Deger-Jalkotzy - Fabrizii-Reuer 2002)

\begin{tabular}{|c|c|c|c|}
\hline Tomb nr. & LH IIIC Late & Submycen. & Early PG \\
\hline T. XCI & $\mathrm{X}$ & & \\
\hline T. XXXII & $\mathrm{x}$ & $\mathrm{x}$ & \\
\hline T. XXXIII & & $\mathrm{x}$ & \\
\hline T. LXII & & $\mathrm{X}$ & \\
\hline T. LXIV & & $\mathrm{x}$ & \\
\hline T. XXXVIII & & $\mathrm{x}$ & $\mathrm{x}$ \\
\hline T. XLIV & & & $\mathrm{x}$ \\
\hline
\end{tabular}

Fig. 2. Elateia-Alonaki: Chronology of burial cremations. (after Dakoronia, Deger-Jalkotzy, Fabrizit-Reuer 2002).

tions were not placed in any container but were simply deposited on the floors or in the pits of a chamber.

I would now like to concentrate on three tombs where cremation burials were discovered (T. XXXVIII/88, T. XLIV/89 and T. LXII/90). The roof of T. LXII had collapsed, the other two were found intact. of 134 individuals. As already mentioned, the roof of the chamber had collapsed. In the debris above the chamber floor a considerable amount of Hellenistic/Roman material was found. Thus it is not surprising that the LBA burials on the floor had not remained undisturbed.

However, in the north-western part of the chamber one burial group was found in situ, and this group pertains to the present discussion. Three skeletons in an extremely contracted position were piled on top of one another (Fig. 4). Two cremations of a woman aged between 20 and 25 years and of a child of 2.5 years at the most were found among them. According to the typology of the burial vases and the finger-rings connected with this group, the five individuals had all been deposited at the beginning of the Submycenaean period. ${ }^{\text {? }}$

Further cremations were found in three of the 10 floor pits which were situated near the walls of the chamber. Pit Alpha was discovered in the NW corner directly beneath the aforementioned burial group, Pit Epsilon was found in the SW corner and Pit Eta in the NE corner (Fig. 3). In other tombs, too, pits with cremations were situated near the chamber walls. Thus it may be imagined that the deposit of cremations followed a certain pattern. At this point it has to be pointed out that in T. LXII not a single fragment of

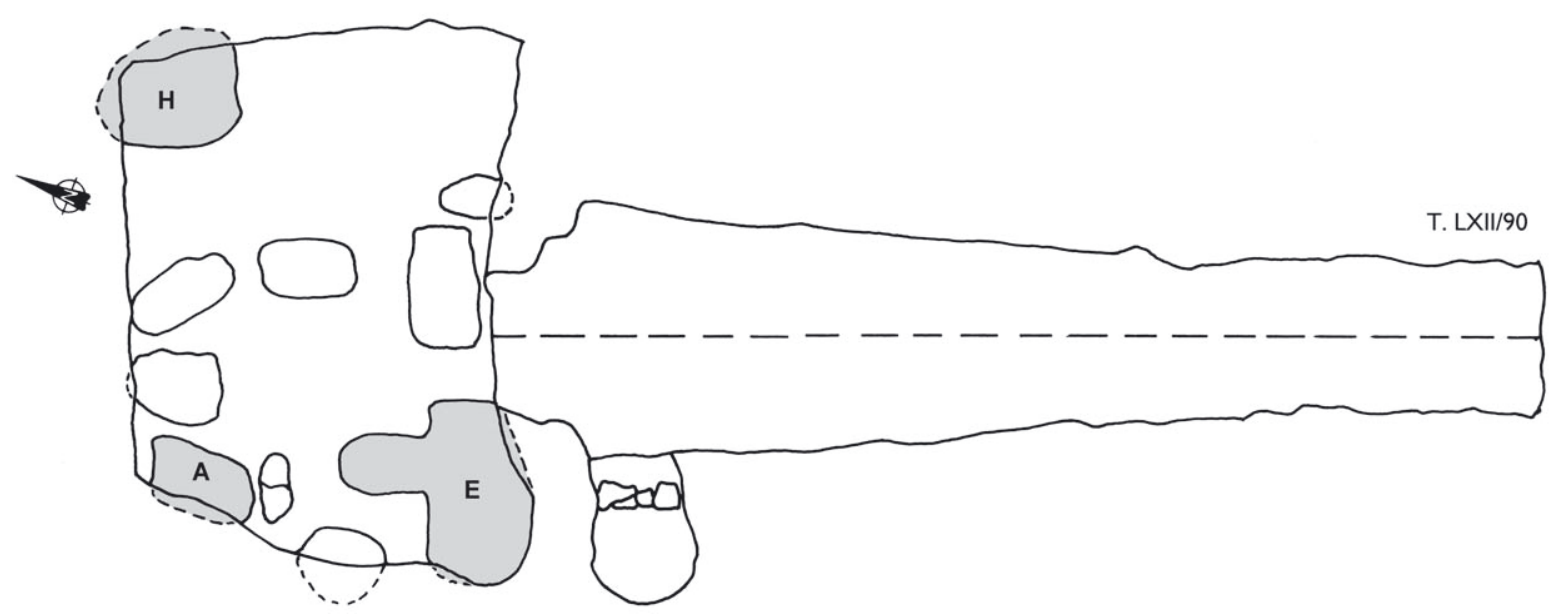

Fig. 3. T. LXII/90: Plan with floor pits (Courtesy Ph. Dakoronia and team. Digitalization: M. Frauenglas).

\section{Tomb LXII/90 (Fig. 3)}

This is one of the largest and richest tombs excavated at Elateia. ${ }^{6}$ It was used for more than 300 years, i.e. from LH IIIA1 to Submycenaean, and contained the remains

6. Dakoronia, Deger-Jalkotzy, Fabrizit-Reuer 2002, 141-145. Deger-JaLKotZy 2009, 79-81, 83 f. cremated bones, deposited in a pit, was found on the floor. The same is true of all the other tombs where cremations have so far been found. Thus, in contrast to the habit of transferring skeletal remains of inhumations to secondary

7. Dakoronia, Deger-Jalkotzy, Fabrizi-Reuer 2002, 141. - DeGER-JALKOTZY 2009, $79 \mathrm{f}$. 


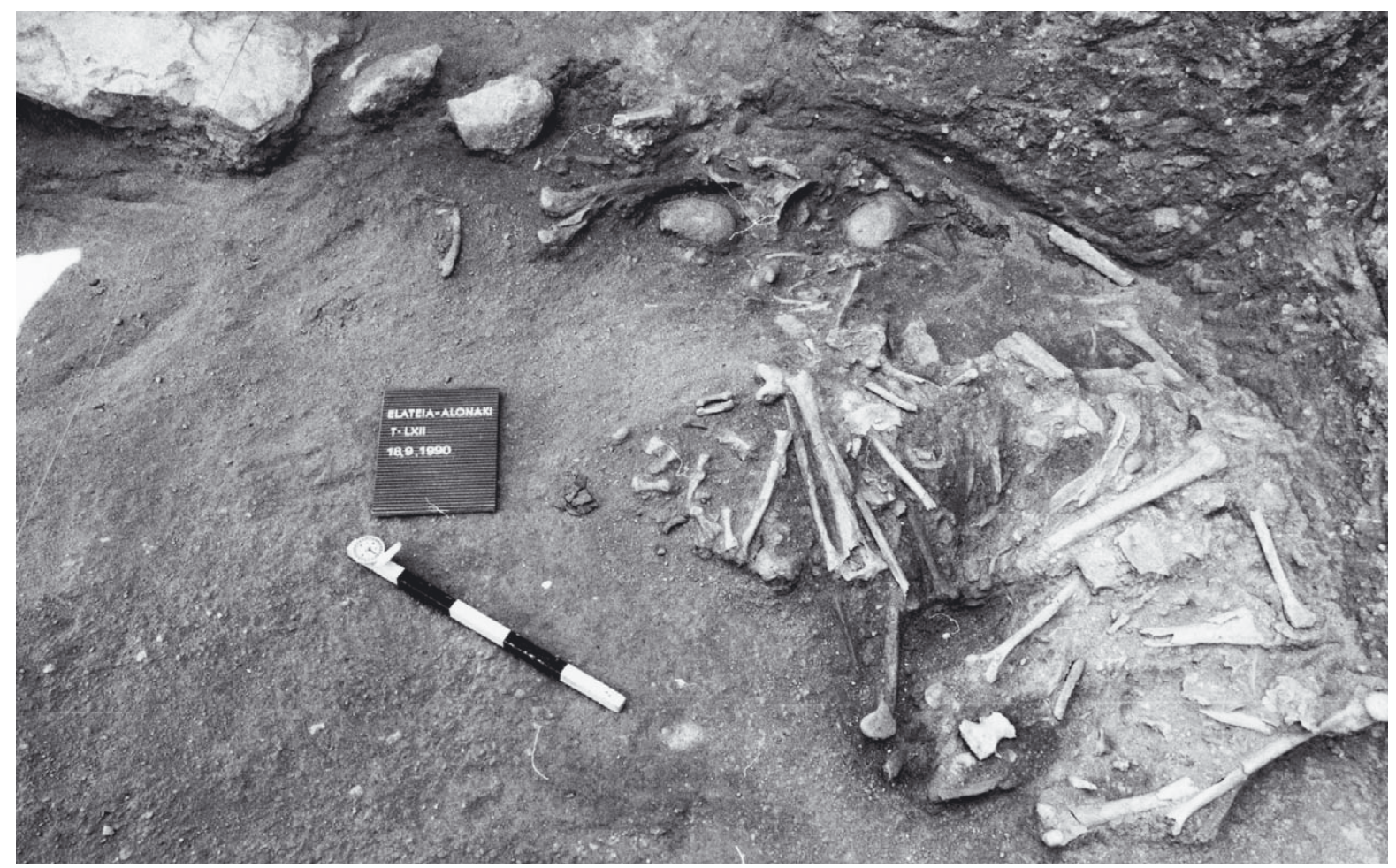

Fig. 4. T. LXII/90: Burial group in NW corner of the chamber (Photo: E. Alram-Stern. Digitalization: M. Frauenglas).

positions (see above) there is no evidence that cremations were first deposited on the floor and later transferred to a pit. Therefore cremations found in pits may be viewed as primary burials, even if the skeletal remains deposited in the same pit had been transferred from some other location in the tomb. It may have been for this reason that the pits situated near the walls of the chamber were favoured for the deposit of cremations.

Pit A which was situated in the north-western corner of T. LXII contained the skeletal remains of seven individuals and two cremations. As in the case of the burial group on top of this pit (see above), the cremations were those of a woman aged between 20 and 25 years and of an approximately 12 month old baby. The only vase found in Pit A can be dated to LH IIIC Late while the finger-rings were of Submycenaean type. Otherwise, the burial gifts can be dated to the $13^{\text {th }}$ and $12^{\text {th }}$ centuries BC. We have argued further above that the cremations deposited in pits should be regarded as primary burials. Under these premises the cremations of Pit A in T. LXII should be synchronized with the latest burial gifts found in the pit dated to LH IIIC Late/Submycenae-

8. Dakoronia, Deger-Jalkotzy, Fabrizit-Reuer 2002, 141. - DeGER-JALKOTZY 2009, 83. an. Moreover, based on the evidence from the pottery and bronze objects the cremations in Pit A and the cremations connected with the burial group on the floor above the pit appear to have been deposited at about the same time or at least soon after one another: the burial vases connected with both groups can be dated to LH IIIC Late / Submycenaean or, in other words, to an early phase of the Submycenaean period. ${ }^{9}$

The contents of $\mathrm{Pit} \mathrm{H}$ in the NE corner of the tomb are very similar to those of Pit A. Apart from the skeletal remains of 19 individuals there were the cremated bones of a woman aged between 20 and 25 years. The pottery is mainly LH IIIC Middle and Late, but two vases exhibit the stylistic features of Submycenaean and as in Pit A there were fingerrings of Submycenaean types. As in the case of Pit A, it may be suggested that the cremation burial was one of the latest deposits of Pit $\mathrm{H}$ dating to the Submycenaean. ${ }^{10}$

The large Pit E contained the skeletal remains of 40 individuals and the cremated remains of a woman aged 20. The chronology of the burial gifts ranges from LH IIIA1

9. Deger-Jalkotzy 2009, 83.

10. Dakoronia, Deger-Jalkotzy, Fabrizit-Reuer 2002, 141. - DeGER-JALKOTZY 2009, $83 \mathrm{f}$. 


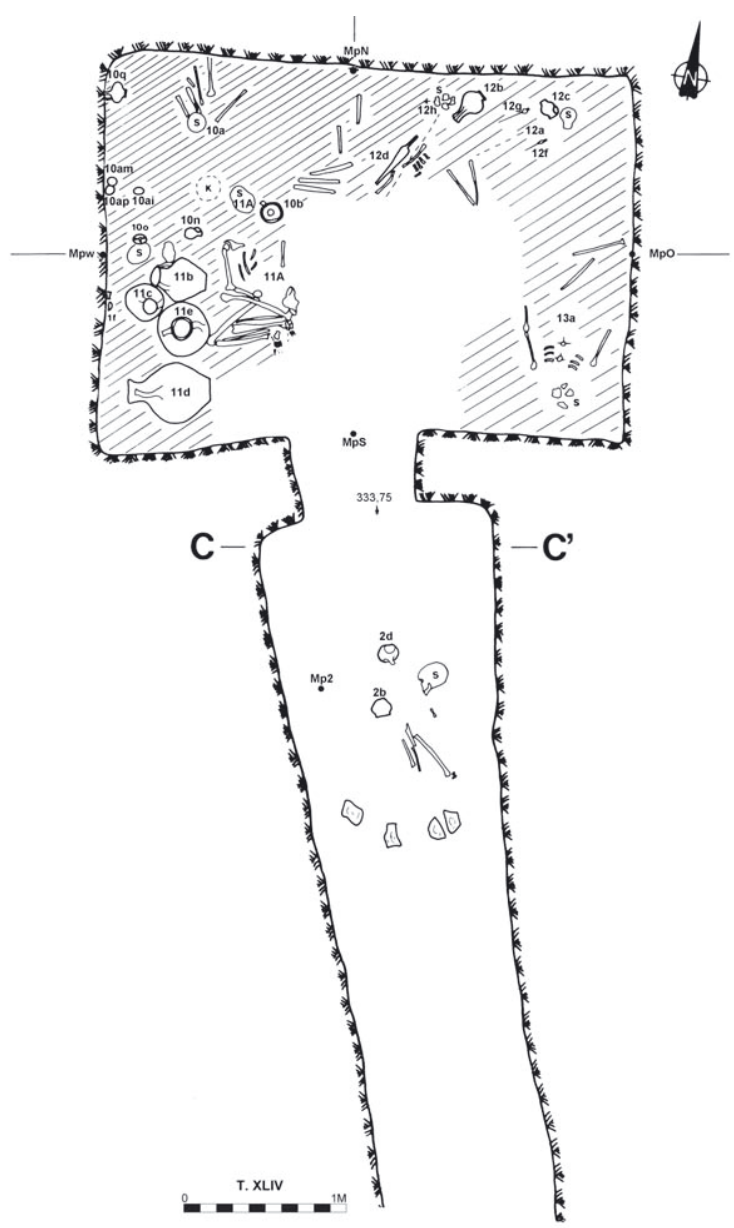

Fig. 5. T. XLVI/89: Plan and finds (Drawings: E. Alram-Stern and team, E. Held. Digitalization: M. Frauenglas).

( $14^{\text {th }}$ century BC) to Submycenaean. Assuming that the cremation burial was found in situ it may be suggested again that the cremation was deposited about the same time when the latest secondary burials of skeletal remains took place in Pit E. Under these premises the date was Submycenaean again. ${ }^{11}$

Summing up T. LXII contained the remains of 134 individuals. Among them there were 6 cremations, 4 of which were of adult women and two of infants. A double cremation (woman and child) deposited on the floor of the tomb was mixed with the remains of three extremely contracted skeletons piled on top of one another. All of them can be dated to the earlier part of the Submycenaean period. The same chronology may be assigned to the cremated remains (two women and another woman-and-child double burial) found in three floor pits.

11. Dakoronia, Deger-Jalkotzy, Fabrizii-Reuer 2002, 141.

\section{Tomb XLIV/89 (Fig. 5)}

This tomb was larger than the average tombs in ElateiaAlonaki but still smaller than T. LXII. ${ }^{12}$ The chamber was of a neat rectangular shape, the angle between the dromos and the entrance of the tomb was slightly oblique. The tomb had no pits.

The earliest finds can be dated to LH IIIC Middle/Advanced. Since there were no pits in the floor it is likely that the tomb was cut at that time.

A post-Mycenaean burial was found in the dromos. It may have been surrounded by a stone enclosure. The skeleton of a woman was accompanied by two Geometric cups dating the burial to the later part of the 9 th century BC..$^{13}$

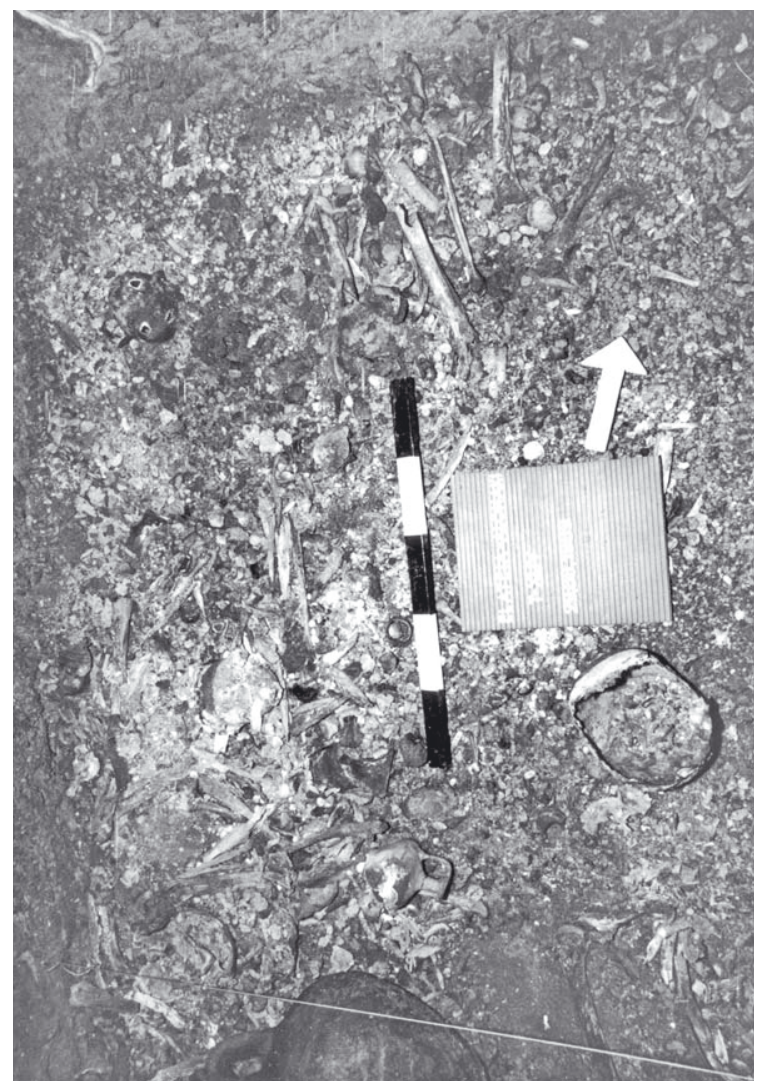

Fig. 6. T. XLIV/89: Burial group in NW corner of the chamber (Photo: E. Alram-Stern. Digitalization: M. Frauenglas).

12. On T. XLIV/89 see also Deger-Jalkotzy 1999, 197 f. - DakoroNia, Deger-Jalkotzy, FAbrizit-Reuer 2002, 146.

13. Deger-JALKotzy in press. 


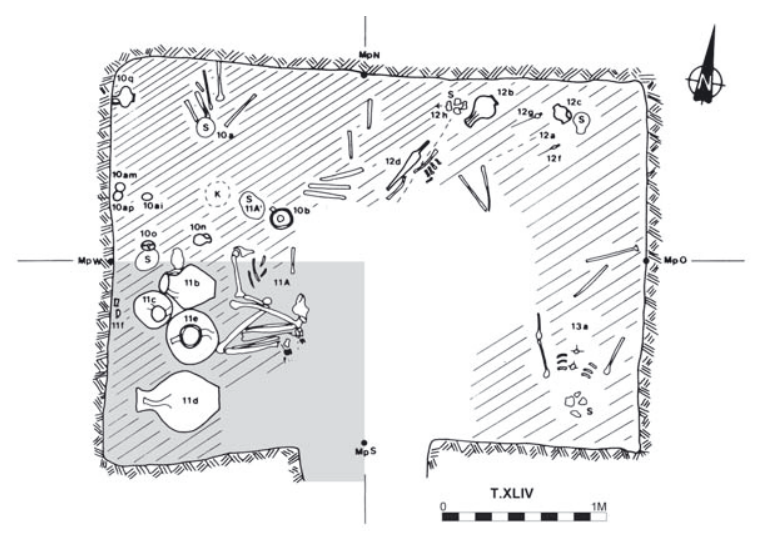

Fig. 7. T. XLIV/89: Burial group in SW corner of the chamber (Drawings: E. Alram-Stern and team, E. Held. Digitalization: M. Frauenglas).

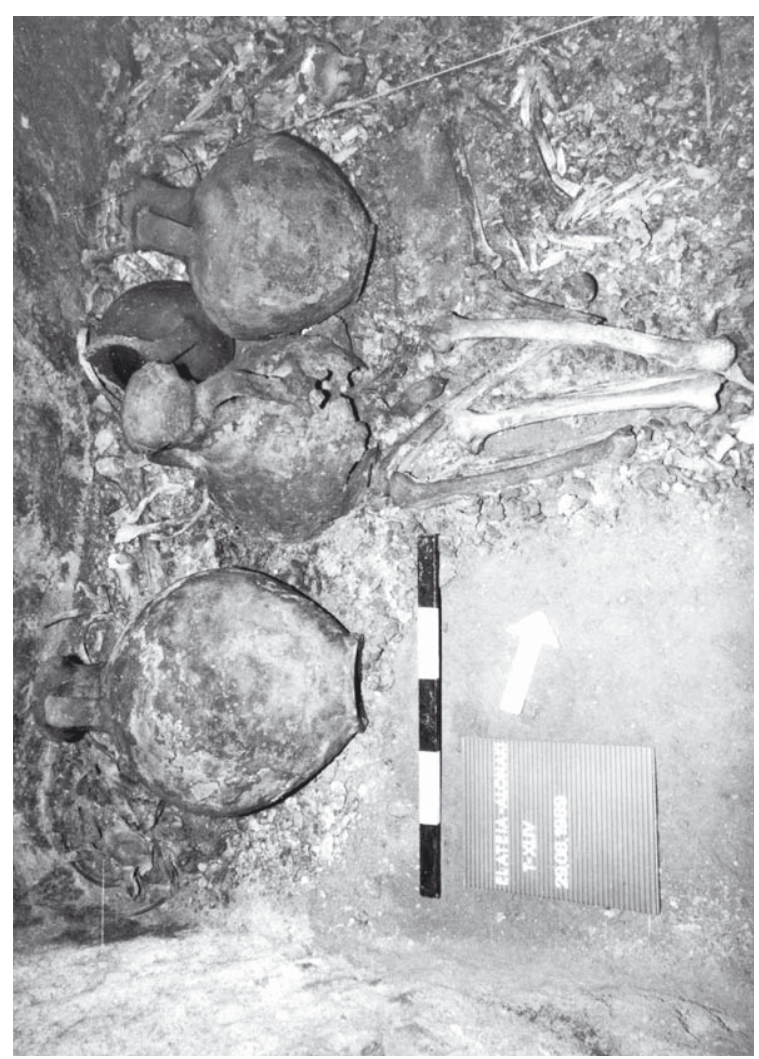

Fig. 8. T. XLIV/89: Burial group in SW corner of the chamber (Photo: E. Alram-Stern. Digitalization: M. Frauenglas).

The floor of the chamber was densely covered with the remains of 21 individuals, 15 of those had been buried in the north-western part of the chamber. Many corpses had been deposited one above another in an extremely contracted position (Fig. 6). Among the skeletal remains there were the burnt bones of an approximately one year old child. The cremation had simply been deposited on the floor without any container. The combination of cremation and heavily contracted interments resembles that of the assemblage in the NW corner of T. LXII (see above). The date of the pottery found in the NW part of the chamber ranges from LH IIIC Middle to Submycenaean. The majority of the pottery connected with the human remains found in the northwestern part of the chamber can be assigned to LH IIIC Late and Submycenaean, and this may well have been the date of the cremation too.

In the north-eastern corner of the tomb the skeletons of a man and a woman were found deposited next to each other. They had been buried at the beginning of the Early Protogeometric period. Although the evidence from these burials is very interesting it does not pertain to the present context. ${ }^{14} \mathrm{~A}$ further skeleton found in situ in the southeastern corner cannot be dated due to the lack of burial gifts.

The final burials of T. XLIV had been deposited in the south-western part of the chamber (Fig. 7). Next to the entrance there was the skeleton of a tall, strong man with contracted legs turned to the right. Three vessels were piled up in front of him (Fig. 8): first there was a handmade amphora, followed by a large handmade jug which served as an ash-urn. ${ }^{15}$ It contained the cremated remains of a small child (approx. one year old). The upper part of a wheel-made amphora which had been heavily damaged by fire and probably by some acid was leant against the urn. The bottom part of the vessel was missing, and there was a mark on the floor beneath it. It may be assumed that the vase had been used in connection with the cremating ceremony. The group was completed by a fourth vessel, a large wheel-made amphora, situated a little further to the south (Fig. 6). The chronology of the four vases can be established as Protogeometric.

In the vicinity of this group there was an Early Geometric cup which cannot be assigned to a particular burial. However, it was the object of the latest date found in the chamber and it may be dated slightly earlier than the two cups from the dromos burial (see above). ${ }^{16}$

14. Nevertheless, it may be mentioned that the man was equipped with a rather dingy weapon composed of two broken iron swords. The woman wore two long dress-pins, one of bronze, the other one made of iron with a globular bronze head. The burial vases consisted of a small jug for the woman and an oinochoe for the man. Cf. DEGERJALKOTZY 1999, 199.

15. For an illustration of this vessel see Deger-Jalkotzy 2009, fig. 15/8 (right).

16. Deger-Jalkotzy in press. 


\section{Tomb XXXVIII/88}

The evidence of this tomb has already been described elsewhere. ${ }^{17}$ The tomb was found intact, the entrance blocked by a slab. The shape of the chamber was roughly circular with a convexity in the northern part of the wall. A large oblong pit, partly covered by a slab, was situated in the centre of the chamber. It contained the remains of four individuals and burial vases dated to LH IIIC Middle/Advanced. No undisturbed inhumation was found on the floor of the chamber. The remains of eight individuals were mainly scattered around the eastern part of the tomb. The pottery chronology of the vases found in this part was LH IIIC Late through Protogeometric.

The evidence of T. XXXVIII pertaining to the present topic was found immediately behind the slab which closed the stomion (entrance). There were two large vessels, an amphora and a large jug which contained what must have been the final burial deposits of the tomb (Fig. 9).

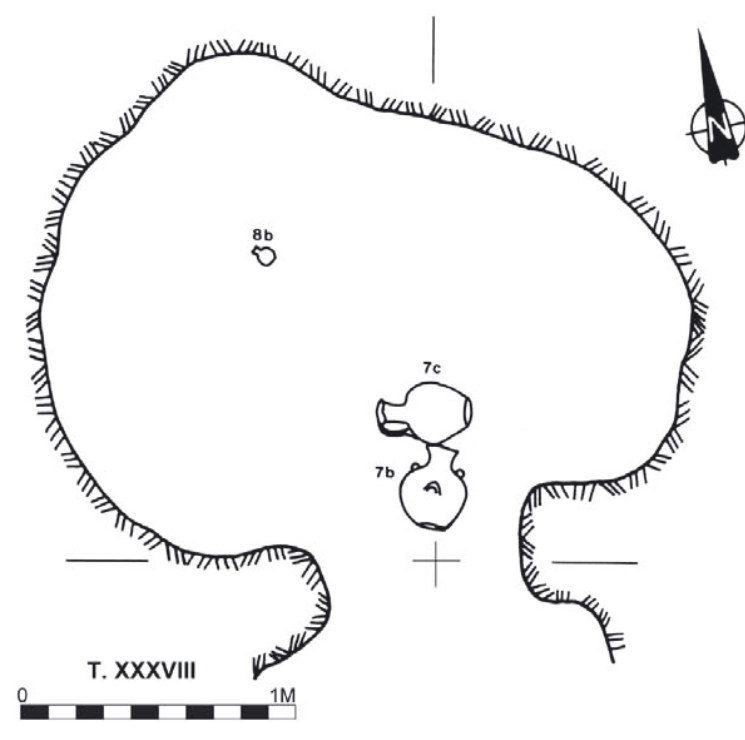

Fig. 9. T. XXXVIII/88: Uppermost burial layer in chamber (Drawings: E. Alram-Stern and team, E. Held. Digitalization: M. Frauenglas).

The amphora contained the cremated remains of a man; in the large jug were those of a woman. Based on the internal evidence of the finds from the tomb the two urns appear to have been deposited during the Protogeometric period. However, the stylistic elements of the amphora suggest that

17. Deger-Jalkotzy 1999, 197. - Dakoronia, Deger-Jalkotzy, FABriZit-Reuer 2002, 138-140. this vessel may well have been of an earlier date. ${ }^{18}$ If this is the case then it was re-used as an ash-urn and deposited in the late 10 th or in the early 9 th century BC.

\section{Summary and Discussion}

As has been already stated, the percentage of cremations at Elateia was very small. There were 23 cremations as opposed to 2000 inhumations, i.e. less than $2 \%$.

Despite the indeterminable gender of some juveniles and children E. Reuer and S. Fabrizii-Reuer were able to prove statistically that more women were cremated than men, as well as more young individuals than old people.

The majority of the cremations were of 11 women $(48 \%)$, followed by three juveniles and seven children (43\%) and two men (9\%).

The age of the cremated individuals ranges from 7 months to 70 years. A very interesting detail is presented by three double cremations consisting each of a woman and of a small child. ${ }^{19}$ As S. Fabrizii-Reuer pointed out, the burnt remains were tightly mixed which suggests that the respective women and children were cremated together. The same is suggested by the identical colouring of the bone remains, as well as by the synchronisms of the deposits. It is very likely that we are dealing with the burials of mothers and children who had either died together or shortly after one another. ${ }^{20}$ One double cremation can be dated to LH IIIC Late, the other two to the early Submycenaean period.

As has been already mentioned the cremations of LH IIIC Late and Submycenaean date were deposited without any container either on the floor or in the pits of the chambers. In contrast, the three ash-urns found in the Elateia-Alonaki tombs were deposited in the Protogeometric period: in T. XXXVIII an amphora was used for the cremated remains of a man and a large jug for those of a woman, whereas in T. XLIV a hand-made jar contained the ashes of a child. Since these are the only urns which have been found at Elateia, it is impossible to tell whether or not there was a relation between vase types and gender or age of the cremated individuals.

Within the area which has been excavated so far there has been no evidence of pyres. It may be concluded that cremations took place at the edge of the cemetery or even outside of it. Whatever burial rites may have taken place they certainly involved the cremation of the corpse on the pyre,

18. See Deger-Jalkotzy 1999, 197.

19. For T. LXII/90 see above. The third instance was discovered in T. LXIII/90, see Dakoronia, Deger-Jalkotzy, FabriziI-Reuer $2002,146 \mathrm{ff}$

20. Dakoronia, Deger-Jalkotzy, Fabrizit-Reuer 2002, 148. 
the collection of the burnt remains, their transfer to the cemetery and the deposition in the tomb. The deposition of cremations in ash-urns was a ritual which did not take place until the Early Iron Age. According to the evidence from T. XLIV it may be assumed that burial gifts such as large amphorae may have been used in the cremation ceremony.

As we have already stated, the burial rite of cremation was introduced at Elateia during the last part of the Mycenaean period and it was practised during the transition from the Bronze Age to the Early Iron Age (Fig. 1). However, many other questions arise. Why was cremation only practised during that period of time? Why were cremations so rare? Why were more women cremated than men and why more young people than old people? It is clear that most questions can only invite speculations.

However, it is remarkable that during the same span of time another deviation from the traditional burial custom at Elateia took place, namely the burial of corpses in a tightly contracted position one upon another, like parcels. Moreover, the numbers of burials in the Elateia-Alonaki cemetery then reached its height. Even pits in the chamber floors were used for primary burials. Furthermore, Submycenaean vases were deposited both on the floor and in the pits of tombs such as T. LXII. Finally, a new type of very small chambertombs was introduced. Therefore the conclusion itself suggests that a rise in population took place at Elateia. ${ }^{21}$

Is it conceivable that cremation was applied as a last resort, in cases when tombs could not be re-opened because of recent burials so that the cremated bones were kept until they could be buried in the tomb?

Another explanation for the introduction of new burial practices at the end of LH IIIC and during the Submycenaean period may be sought in the presence of a new population group. Initially, 23 cremation burials cannot be regarded as being accidental as it takes certain techniques and a certain experience to cremate a human being. Even if the number of cremations is marginal, it cannot be excluded that during the transition from the Late Bronze to the Early Iron Age a new population group arrived who was responsible for practising this burial rite. After all, Elateia is situated at the major crossroads in Greece from the north to the south and from the east to the west. Moreover, several new elements among the burial gifts, which made their first appearance during that same time span, such as long dress pins, special types of finger-rings, weapons and handmade vases with incised decoration, were found. They may have originated in regions where cremation, too, was an element of the spiritual culture.

21. See Deger-Jalkotzy 2009.
However, it should be underlined again that cremation at Elateia was a short-lived and transitory phenomenon. The final cremations in the Mycenaean chamber-tombs were deposited during the Protogeometric period. Moreover, during the Early Protogeometric period the number of burials in the Elateia-Alonaki cemetery generally declined, and only a limited number of tombs were used beyond the 10 th century BC. The Geometric burial in the dromos of $\mathrm{T}$. XLIV is a case in point. Interestingly enough those final burials at Elateia-Alonaki were inhumations. In contrast, in other regions in Greece, such as Attica and Euboea, cremation burials rose and became the dominant burial practice during the Early Iron Age. Therefore, if the increase in burials during the Submycenaean period at Elateia was, indeed, caused by immigrants, these people did not stay for good - or, at least, not all of them stayed. Some may have moved elsewhere in the vicinity ${ }^{22}$, others certainly moved further afield. Thus the evidence from Elateia appears to represent a contribution to the discussion of population movements during the time of transition from the Late Bronze to the Early Iron Age in Greece - not least to the movements of the famous "Dorians".

\section{Bibliography}

Dakoronia, Deger-Jalkotzy, Fabrizit-Reuer 2002

P. Dakoronia, S. Deger-Jalkotzy, S. Fabrizi-Reuer, Beisetzungen mit Leichenbrand aus der Felskammernekropole von Elateia-Alonaki, Griechenland, ArchA 84-85, 2000-2001, 137-153.

Deger-Jalkotzy 1999

S. Deger-Jalkotzy, Elateia and Problems of Pottery Chro-

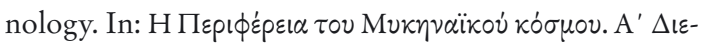

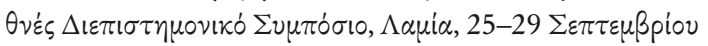
1994, Lamia 1999, 195-202.

Deger-Jalkotzy 2007

S. Deger-Jalkotzy, Defining LH IIIC Middle at the Cemetery of Elateia-Alonaki in Central Greece. In: S. DegerJalkotzy, M. Zavadil (eds.), LH III C Chronology and Synchronisms II. Proceedings of the International Workshop held at the Austrian Academy of Sciences at Vienna, October 29th and 30th, 2004, Veröffentlichungen der Mykenischen Kommission 28, Vienna 2007, 129-159.

Deger-Jalkotzy 2009

S. Deger-Jalkotzy, From LH IIIC Late to the Early Iron Age: The Submycenaean Period at Elateia. In: S. DegerJalkotzy, A. E. BÄChle (eds.), LH III C Chronology and Synchronisms III. LH III C Late and the Transition

22. Discussed further in Deger-Jalkotzy in press. 
to the Early Iron Age. Proceedings of the International Workshop held at the Austrian Academy of Sciences at Vienna, February 23rd and 24th, 2007, Veröffentlichungen der Mykenischen Kommission 30, Vienna 2009, 79-116.

Deger-Jalkotzy in press

S. Deger-Jalkotzy, Geometric pottery from Elateia-Alonaki: The end of a long history. Submitted for Festschrift Phanouria Dakoronia, Lamia, in press.

Grupe, Herrmann 1983

G. Grupe, B. Herrmann, Über das Schrumpfungsverhalten experimentell verbrannter spongiöser Knochen am Beispiel des caput femoris, Zeitschrift für Morphologie und Anthropologie 74, 1983, 121-127.

Lis 2009

B. Lis, The sequence of Late Bronze/Early Iron Age pottery from Central Greek settlements - a fresh look at old and new evidence. In: S. Deger-Jalkotzy, A. E. Bächle (eds.), LH III C Chronology and Synchronisms III. LH III C Late and the Transition to the Early Iron Age. Proceedings of the International Workshop held at the Austrian Academy of Sciences at Vienna, February 23rd and 24th, 2007, Veröffentlichungen der Mykenischen Kommission 30, Vienna 2009, 203-233.

Univ.-Prof. Dr. Sigrid Deger-Jalkotzy

Mykenische Kommission

Österreichische Akademie der Wissenschaften

Postgasse 7

A-1010 Wien

sigrid.deger-jalkotzy@oeaw.ac.at 